Arab Univ. J. Agric. Sci., Ain Shams Univ., Cairo, Egypt 28(3), 809-827, 2020

Website: http://ajs.journals.ekb.eg

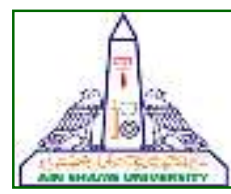

809

\title{
OPTIMIZATION OF AMINO ACID PRODUCTION FROM CHICKEN FEATHER BY BACILLUS AMYLOLIQUEFACIENS USING RESPONSE SURFACE METHODOLOGY AS A NEW TOOL FOR POWDERY MILDEW DISEASE BIOCONTROL
}

\author{
Samah H. Abu-Hussien ${ }^{1^{*}}$ and Maha H. Mohamed ${ }^{2}$ \\ 1- Agricultural Microbiology Dept., Fac. of Agric., Ain Shams Univ., P.O. Box 68, Hadayek Shoubra 11241, \\ Cairo, Egypt \\ 2- Plant Pathology Dept., Fac. of Agric., Ain Shams Univ., P.O. Box 68, Hadayek Shoubra 11241, Cairo, \\ Egypt
}

*Corresponding author: samah_hashem1@ @agr.asu.edu.eg

Received 22 March, 2020

Accepted 20 April, 2020

\begin{abstract}
The present work aimed to optimize amino acids production by Bacillus amyloliquefaciens 35s from chicken feather using response surface methodology (RSM) and applying the produced amino acids in biological control of powdery mildew disease. Variables affecting amino acids production from $\mathrm{B}$. amyloliquefaciens 35s were screened using Plackett Burman design. Factors showed to be significant to produce amino acids were optimized using central composite design (CCD) of RSM at three coded levels $(-1,0,+1)$. All obtained data were analyzed by ANOVA with post hoc multiple comparison analysis performed using Tukey's HSD. TGY (tryptone, glucose, yeast extract) was the basal medium. Impacts of medium components were studied using Plackett-Burman design. "Design Expert 12" StateEase was used to analyze the experimental Plackett- Burman design. Feather, yeast extract, $\mathrm{CaCO}_{3}$, $\mathrm{KH}_{2} \mathrm{PO}_{4}$ and agitation rate (using shake flask) were optimized statistically by the CCD design of the RSM. Validation of statistical model of the medium components was done by carrying out the experiment at optimum conditions of the process parameters as determined by the model. Amino acids types were identified by amino acid analyzer. Among the significant medium components, feather, yeast extract, $\mathrm{CaCO}_{3}, \mathrm{KH}_{2} \mathrm{PO}_{4}$ and agitation rate showed to have significant effect on amino acids production. Predicted maximum amino acids production was observed near the mid-point concentrations of the
\end{abstract}

mentioned above factors and the experimental value $(6.55 \mathrm{~g} / \mathrm{l})$ was very close to the predicted value of $(6.60 \mathrm{~g} / \mathrm{l})$ predicted by the model. Amino acid analyzer analysis for the produced amino acids shows the release of asparagine, threonine, serine, glutamine, proline, glycine, alanine, cysteine, valine, methionine, isoleucine, leucine, tyrosine, phenyl alanine, histidine, lysine and arginine, respectively. Effect of chicken feather hydrolysate on cucumber powdery mildew disease was tested by applying foliar application with different concentrations $(0,5$, 10,15 , and $20 \% \mathrm{v} / \mathrm{v}$ ), then degree of infection and sporulation on cucumber plants were assessed. The lowest concentration of chicken feather hydrolysate showed the lowest effect on disease index. Conversely, cucumber resistance increased by the increasing of feather's hydrolysate concentrations associated with a clear reduction in the disease index and sporulation. Aside from, extra foliar application showed a decrease in the disease index for all concentrations compared with untreated plants. Foliar application with $20 \%$ concentration of chicken feather hydrolysate had the highest stimulation of the studied oxidative enzymes i.e., peroxidase (POX), phenylalanine ammonia-lyase (PAL), polyphenol oxidase (PPO) and superoxide dismutase (SOD).

Keywords: Chicken feather hydrolysate; Bacillus amyloliquefaciens 35s; Amino acids; RSM; Biocontrol; Powdery mildew; Cucumber; Oxidative enzymes. 


\section{INTRODUCTION}

Nine million tons of feathers are produced each year all around the world as a cheap by-product during the poultry processing industry. It composed of about $90 \%$ protein as keratin, one of the fibrous and insoluble structural proteins, due to the presence of hydrogen, cysteine di-sulphide bonds, and hydrophobic interlinkages. Acid hydrolysis of keratin using trypsin, papain and pepsin is difficult because of its high mechanical strength and its slow degradation process in nature. Hydrolyzing feathers by the traditional physical and chemical methods conducts a big loss in its amino acids content as lysine and methionine. Contrarily, feathers microbial biodegradation is an alternative tool for keratin wastes hydrolyzing. So, biodegradable feathers using bacteria such as Bacillus spp (Tamreihao et al 2017) are considered one of the rich sources of valuable proteins and essential amino acids (D'Este et al 2018). In fact, not only, hazardous chemical processes can be replaced by microbial hydrolysis of keratin. (Box and Wilson, 1951) but also, it provides a cheap and a mild reaction conditions to produce essential amino acids (Chauhan and Gupta, 2004) as it is applied as a biocontrol agent against plant pathogens (Joo and Chang, 2006).

Powdery mildew is a disease infects greenhouse and field grown cucumber plants widely (Rankovic, 2003; Cosme et al 2012). The common pathogens of this disease are Podosphaera xanthii (syn Podosphaera fuliginea) and Golovinomyces cichoracearum (syn Erysiphe cichoracearum). Zitter et al (1996) affirmed that growth and pathogenicity of $P$. xanthii increased rapidly under greenhouse conditions. Powdery mildew symptoms form white powder growth -talcum like- on leaf surfaces and stems of cucumber plants. As proved by (McGrath 1996; Dik et al 2004), fungal growth on plant surfaces not only disrupt photosynthesis and respiration processes leading to leaves fade and death but also, reduce both of quantitative and qualitative cucumber yield. Chemical control is commonly used tool for controlling the disease. However, it is not an efficient way due to the control of $P$. xanthii with fungicides (Reuveni et al 1996). Moreover, chemicals are not eco-friendly causing harmful effects for ecosystems. Therefore, it is needed indeed to find alternative eco- friendly tools to control the disease. Recently, many researchers have provided the effective role of amino acids on controlling of plant pathogens. According to (Zheng et al 2011), increasing enzymatic activities of polyphenol oxidase,phenylalanine ammonia-lyase and chitinase, $\beta-1,3-$ glucanase leads to reduce the tomato fruit lesion size by Botrytis cinerea and activates plant defense when spraying the green mature tomato fruits using different levels of arginine as $0.5,1$, and $5 \mathrm{mM}$, respectively. Also, Bahadur et al (2012) found that applying foliar spraying on pea leaves by different concentrations of L-phenylalanine (50, 100 and $150 \mathrm{ppm}$ ) resulted in increasing the PAL activity as well as reduction in the spore germination of the pathogenic Erysiphe pisi. In the same manner, Hasabi et al (2014) showed that foliar spraying of L- methionine on lime leaves resulted in a significant reduction of canker lesions as well as significantly increasing of the plant induced resistance by the way of increasing the activities of both phenylalanine ammonia-lyase and peroxidase enzymes compared to control treatments. Using small doses of amino acids (glutamate, cysteine, phenylalanine, and glycine) by foliar application or seed treatment led to increase the activity of antioxidant enzymes (phenylalanine ammonia-lyase, peroxidase, and polyphenol oxidase) in soybean plants (Teixeira et al 2017). Therefore, the aim of the current research was to identify significant variables affecting amino acids production during biodegrading of feathers by $B$. amyloliquefaciens. Then, evaluating the recycling of chicken feathers as an effective and low cost alternative controlling powdery mildew diseases in cucumber.

\section{MATERIALS AND METHODS}

\section{Microorganism}

B. amyloliquefaciens 35s strain was previously isolated from feather waste in Cairo, Egypt and identified (Nassar et al 2015). For culture maintenance, nutrient agar slants were inoculated with loopful of the strain and maintained at $4^{\circ} \mathrm{C}$. Subculturing was done every month. Nutrient agar composed of $(\mathrm{g} / \mathrm{l})$ : beef extract 3, peptone 5, agar 15 .

\section{Hydrolysis of chicken feather}

Chicken feathers were obtained by their collection from local poultry slaughterhouse in Cairo, Egypt. Obtaining of chicken feather hydrolysate was performed as described by (Nassar et al 2015). Prepared chicken feather meal powder was maintained at room temperature for further studies. 


\section{Optimization of Amino Acid Production from Chicken Feather by Bacillus Amyloliquefaciens Using Response Surface Methodology as a New Tool for Powdery Mildew Disease Biocontrol}

\section{Standard inoculum}

Standard inoculum was prepared by inoculating $50 \mathrm{ml}$ of TGY broth medium composed of ( $\mathrm{g} / \mathrm{l})$ : tryptone (10), glucose (10), yeast extract (5) in $250 \mathrm{ml}$ conical flasks with a loop of tested culture. The inoculated flask was incubated on a rotary shaking incubator (Lab-line Inc. Ltd.) at the rate of $120 \mathrm{rpm}$ for $24 \mathrm{~h}$ at $37^{\circ} \mathrm{C}$ and considered as the standard inoculum ( $1 \mathrm{ml}$ contained $6.0-7.0 \times 105$ viable cells) for shake flasks.

\section{Plackett-Burman design (PBD) for screening of the growth culture main parameters}

PBD was used to screen the main significant medium components according to their main effects using a 12 trial Plackett- Burman experiments through one-way ANOVA by "Design Expert ${ }^{\circledR}$ 12.0" Stat-Ease, Inc., Minneapolis, USA, ten ingredients were selected for the study at two factor levels, high $(+1)$ and low (-1) Table 1. Feather, glucose, yeast extract, peptone, $\mathrm{CaCO}_{3}, \mathrm{KH}_{2} \mathrm{PO}_{4}$, temperature, $\mathrm{pH}$, inoculum size agitation speed and incubation time. Table 2 records the factor name, symbol code, and coded levels of the screened variable parameters. Main media components and their levels used in the experimental design using the symbol code and the actual level of the variables. All flasks were inoculated and incubated at $37^{\circ} \mathrm{C}$ at $150 \mathrm{rpm}$ for 24 h. for performing the total amino acid assay.

\section{Central Composite Design (CCD) design for optimization of media components levels}

According to the results obtained from placket Burman design, five parameters (feather, yeast extract, $\mathrm{CaCO}_{3}, \mathrm{KH}_{2} \mathrm{PO}_{4}$ and agitation rate) were selected as the main significant factors for amino acids production. Optimization was done using a 31 full factorial CCD design. Tables $\mathbf{3}$ and $\mathbf{4}$ showed both of the minimum and maximum levels of parameters tested according to their actual and coded values. Concerning the achievement of experiments, the maximum average of amino acids production was studied as the dependent variable parameter or response (Y). Multiple regression method was calculated to fit the second order polynomial equation in the recorded data. The model equation for this fivefactor system was:
$A A=-142.21571+12.98718$ feather +44.24693 yeast extract+5.56997 $\mathrm{CaCO}_{3}+78.35570 \quad \mathrm{KH}_{2} \mathrm{PO}_{4}+$ 0.786464 agitation +0.064500 feather * yeast extract-0.040571 feather * $\mathrm{CaCO}_{3}-0.465000$ feather * $\mathrm{KH}_{2} \mathrm{PO}_{4}-0.001845$ feather * agitation- 0.032500 yeast extract * $\mathrm{CaCO}_{3}-3.08333$ yeast extract * $\mathrm{KH}_{2} \mathrm{PO}_{4}-0.021650$ yeast extract * agitation +1.42857 $\mathrm{CaCO}_{3}$ * $\mathrm{KH}_{2} \mathrm{PO}_{4}+0.005200$ caco3 * agitation + $0.013167 \mathrm{KH}_{2} \mathrm{PO}_{4}$ * agitation -0.395855 feather $^{2}$ 6.04386 yeast extract ${ }^{2}-0.507662 \mathrm{CaCO}_{3}{ }^{2}-16.17172$ $\mathrm{KH}_{2} \mathrm{PO}_{4}^{2}-0.002195$ agitation ${ }^{2}$. Fisher's test and correlation coefficient $\left(R^{2}\right)$ was calculated to identify the equation's fit quality. The relationship between the amino acid $(Y)$ and the studied parameters' levels were illustrated by a 3D surface graphs according to (Reddy et al 2008).

\section{Extraction and determination of total amino acids}

Crude amino acids were collected by centrifuging culture at $10000 \mathrm{rpm}$ under cooling for $15 \mathrm{~min}$. Pellets were collected to determine cells dry weight and supernatant was used for amino acids identification analysis (Lassoued et al 2015). Determination of total amino acids was done as described by (Anson, 1938).

\section{Chromatographic conditions for free amino acids analysis}

The chromatographic conditions for analysis, using an Amino Acid Analyzer (Sykam, SW), equipped with a visible detector, was used for the individual free amino acid analysis. LC AKO6 $\mathrm{Na}$ 24050313 column (4.6 mm $150 \mathrm{~mm}$ ) was used for free amino acid determination. Immediately after injection onto the columns, an auto-sampler was used for the inline-derivatization by Ninhydrin (NIN) postcolumn derivatization. The NIN-derivatized amino acids were monitored at $570 \mathrm{~nm}$ and at $440 \mathrm{~nm}$. The purchased standards of each individual amino acid (Sykam SW) were used for identification and quantification (external standard method). Individual free amino acid values were expressed as $\mathrm{mg} / \mathrm{l}$ of the production medium. 
Table 1. Media component levels studied in Plackett-Burman design

\begin{tabular}{|l|c|c|c|}
\hline \multirow{2}{*}{ Variable Factors } & \multirow{2}{*}{ Symbols } & \multicolumn{2}{|c|}{ Coded levels } \\
\cline { 3 - 4 } & & $-1(\mathrm{Low})$ & +1 (High) \\
\hline Feather $(\mathrm{g} / \mathrm{l})$ & $\mathrm{A}$ & 10.00 & 20.00 \\
\hline Glucose $(\mathrm{g} / \mathrm{l})$ & $\mathrm{B}$ & 0.0000 & 10.00 \\
\hline yeast extract $(\mathrm{g} / \mathrm{l})$ & $\mathrm{C}$ & 0.0000 & 2.00 \\
\hline Peptone $(\mathrm{g} / \mathrm{l})$ & $\mathrm{D}$ & 0.0000 & 2.00 \\
\hline $\mathrm{CaCO}_{3}(\mathrm{~g} / \mathrm{l})$ & $\mathrm{E}$ & 3.00 & 10.00 \\
\hline $\mathrm{KH}_{2} \mathrm{PO}_{4}(\mathrm{~g} / \mathrm{l})$ & $\mathrm{F}$ & 0.1000 & 1.20 \\
\hline${\mathrm{Temperature}\left({ }^{\circ} \mathrm{C}\right)}^{\mathrm{N}}$ & $\mathrm{G}$ & 30.00 & 42.00 \\
\hline pH & $\mathrm{H}$ & 6.00 & 8.00 \\
\hline inoculum size $(\%)$ & $\mathrm{J}$ & 3.00 & 7.00 \\
\hline Agitation $(\mathrm{rpm})$ & $\mathrm{K}$ & 100.00 & 200.00 \\
\hline Incubation time $(\mathrm{h})$ & $\mathrm{L}$ & 24 & 72 \\
\hline
\end{tabular}

Table 2. Plackett-Burman design model for media components optimization.

\begin{tabular}{|c|c|c|c|c|c|c|c|c|c|c|c|}
\hline $\begin{array}{l}\text { Run } \\
\text { Order }\end{array}$ & $\begin{array}{c}(\mathrm{A}) \\
\text { Feather } \\
(\mathrm{g} / \mathrm{l})\end{array}$ & $\begin{array}{c}(\mathrm{B}) \\
\text { Glucose } \\
(\mathrm{g} / \mathrm{l})\end{array}$ & $\begin{array}{c}(\mathrm{C}) \\
\text { yeast } \\
\text { extract } \\
(\mathrm{g} / \mathrm{l})\end{array}$ & $\begin{array}{c}\text { (D) } \\
\text { Peptone } \\
(\mathrm{g} / \mathrm{l})\end{array}$ & $\begin{array}{c}(\mathrm{E}) \\
\mathrm{CaCO3} \\
(\mathrm{g} / \mathrm{l})\end{array}$ & $\begin{array}{c}(\mathrm{F}) \\
\mathrm{KH} 2 \mathrm{PO} 4 \\
(\mathrm{~g} / \mathrm{l})\end{array}$ & $\begin{array}{c}(\mathrm{G}) \\
\text { Temp. } \\
\left({ }^{\circ} \mathrm{C}\right)\end{array}$ & $\begin{array}{l}\text { (H) } \\
\mathrm{pH}\end{array}$ & $\begin{array}{c}(\mathbf{J}) \\
\text { inoculum } \\
\text { size (\%) }\end{array}$ & $\begin{array}{c}(\mathrm{K}) \\
\text { Agitation } \\
(\mathrm{rpm})\end{array}$ & $\begin{array}{c}\text { (L) } \\
\text { incubation } \\
\text { time (h) }\end{array}$ \\
\hline 1 & +1 & +1 & -1 & -1 & -1 & +1 & -1 & +1 & +1 & -1 & +1 \\
\hline 2 & -1 & -1 & +1 & -1 & +1 & +1 & -1 & +1 & +1 & +1 & -1 \\
\hline 3 & -1 & -1 & -1 & +1 & -1 & +1 & +1 & -1 & +1 & +1 & +1 \\
\hline 4 & +1 & -1 & +1 & +1 & +1 & -1 & -1 & -1 & +1 & -1 & +1 \\
\hline 5 & -1 & +1 & -1 & +1 & +1 & -1 & -1 & +1 & +1 & -1 & -1 \\
\hline 6 & +1 & +1 & -1 & +1 & +1 & +1 & -1 & -1 & -1 & +1 & -1 \\
\hline 7 & +1 & -1 & -1 & -1 & +1 & -1 & +1 & +1 & -1 & +1 & +1 \\
\hline 8 & -1 & +1 & +1 & +1 & -1 & -1 & -1 & +1 & -1 & +1 & +1 \\
\hline 9 & +1 & +1 & +1 & -1 & -1 & -1 & +1 & -1 & +1 & +1 & -1 \\
\hline 10 & -1 & +1 & +1 & -1 & +1 & +1 & +1 & -1 & -1 & -1 & +1 \\
\hline 11 & +1 & -1 & +1 & +1 & -1 & +1 & +1 & +1 & -1 & -1 & -1 \\
\hline 12 & -1 & -1 & -1 & -1 & -1 & -1 & -1 & -1 & -1 & -1 & -1 \\
\hline
\end{tabular}

Table 3. Media components levels in central composite (CCD) design

\begin{tabular}{|l|l|l|l|l|}
\hline \multirow{2}{*}{ Variable } & \multirow{2}{*}{ Symbol } & \multicolumn{3}{|c|}{ Levels of the variables tested in CCD } \\
\cline { 3 - 5 } & & $\mathbf{- 1}($ Low) & $\mathbf{0}$ (mean) & $\mathbf{+ 1}$ (High) \\
\hline Feather & (A) & 10 & 15 & 20 \\
\hline Yeast extract & (B) & 2 & 3 & 4 \\
\hline $\mathrm{CaCO}_{3}$ & (C) & 3 & 6.5 & 10 \\
\hline $\mathrm{KH}_{2} \mathrm{PO}_{4}$ & (D) & 1.2 & 1.35 & 1.5 \\
\hline Agitation & (E) & 100 & 200 & 200 \\
\hline
\end{tabular}



Amyloliquefaciens Using Response Surface Methodology as a New Tool for Powdery Mildew Disease Biocontrol

Table 4. CCD design of the medium five components for optimization of amino acids production

\begin{tabular}{|c|c|c|c|c|c|}
\hline $\begin{array}{l}\text { Run } \\
\text { Order }\end{array}$ & $\begin{array}{c}(A) \\
\text { Feather } \\
(\mathrm{g} / \mathrm{l})\end{array}$ & $\begin{array}{c}\text { (B) } \\
\text { yeast extract } \\
(\mathrm{g} / \mathrm{l})\end{array}$ & $\begin{array}{c}(\mathrm{C}) \\
\mathrm{CaCO} 3 \\
(\mathrm{~g} / \mathrm{I})\end{array}$ & $\begin{array}{c}\text { (D) } \\
\text { KH2PO4 } \\
(g / l)\end{array}$ & $\begin{array}{l}\text { (E) } \\
\text { Agitation } \\
\text { rpm }\end{array}$ \\
\hline 1 & 0 & 0 & -1 & 0 & 0 \\
\hline 2 & +1 & -1 & +1 & +1 & -1 \\
\hline 3 & +1 & +1 & +1 & -1 & -1 \\
\hline 4 & 0 & 0 & 0 & 0 & -1 \\
\hline 5 & +1 & +1 & -1 & -1 & +1 \\
\hline 6 & +1 & -1 & -1 & +1 & +1 \\
\hline 7 & 0 & -1 & 0 & +1 & 0 \\
\hline 8 & 0 & 0 & 0 & 0 & 0 \\
\hline 9 & 0 & 0 & 0 & 0 & 0 \\
\hline 10 & +1 & +1 & -1 & +1 & -1 \\
\hline 11 & 0 & 0 & 0 & 0 & 0 \\
\hline 12 & -1 & +1 & -1 & -1 & -1 \\
\hline 13 & 0 & 0 & +1 & 0 & 0 \\
\hline 14 & +1 & -1 & +1 & -1 & +1 \\
\hline 15 & -1 & +1 & +1 & +1 & -1 \\
\hline 16 & 0 & +1 & 0 & 0 & 0 \\
\hline 17 & 0 & 0 & 0 & 0 & +1 \\
\hline 18 & 0 & 0 & 0 & 0 & 0 \\
\hline 19 & -1 & +1 & +1 & -1 & +1 \\
\hline 20 & 0 & 0 & 0 & 0 & 0 \\
\hline 21 & -1 & 0 & 0 & 0 & 0 \\
\hline 22 & 0 & 0 & 0 & 0 & 0 \\
\hline 23 & +1 & +1 & +1 & +1 & +1 \\
\hline 24 & +1 & -1 & -1 & -1 & -1 \\
\hline 25 & +1 & 0 & 0 & 0 & 0 \\
\hline 26 & -1 & +1 & -1 & +1 & +1 \\
\hline 27 & -1 & -1 & -1 & -1 & +1 \\
\hline 28 & 0 & 0 & 0 & -1 & 0 \\
\hline 29 & 0 & -1 & 0 & 0 & 0 \\
\hline 30 & -1 & -1 & -1 & +1 & -1 \\
\hline 31 & -1 & -1 & +1 & +1 & +1 \\
\hline
\end{tabular}

\section{Amino acids production parameters}

Productivity $(\mathrm{P})=$ Amount of amino acids produced $\left(\mathrm{gl}^{-1}\right) /$ fermentation time $(\mathrm{h})=\mathrm{gl}^{-1} \mathrm{~h}^{-1}$. Aqueous various concentrations of feathers disintegration $(0,5,10,15 \& 20 \%)$ were autoclaved at $121^{\circ} \mathrm{C}$ before used for cucumber plant treatments.

\section{Plant material}

Cucumber seeds (Cucumis sativus L., cV. Beta Alpha) were grown in plastic pots $(150 \mathrm{~mm}$ diameter) filled with a mixture of sand and clay soil (1:1, $\mathrm{v} / \mathrm{v})$, one seed was sown per pot. The plants were watered daily, and fertilized once a week with $0.1 \%$ NPK (20:20:20). Plants were kept under normal greenhouse conditions.
Treatment and inoculation of Podosphaera xanthii on cucumber plants

Plant treatments after 28 days of planting (plants had the third fully expanded true leaves). In this stage plants were sprayed with different concentrations of amino acids (0, 5, 10, $15 \& 20 \%)$, control plants were sprayed with distilled water. Ten replicates were used for each treatment. Conidia spores of Podosphaera xanthii were obtained from "eldgrown" plants, naturally infected cucumber leaves at field-grown cucumber plants in Qualubiya Governorate, Egypt, used as inoculum source. After $24 \mathrm{~h}$. from treatment, conidia were gently shaken to infect the upper surface of cucumber leaves. All plants were covered with polyethylene bags to maintain 
relative humidity for $24 \mathrm{~h}$. An additional foliar spray was performed 13 days after inoculation.

\section{Determination of disease index and sporulation}

Disease index was assessed at the $11^{\text {th }}$ and $20^{\text {th }}$ days after inoculation (Twelve days after first treatment, and seven days after extra foliar application) visually using a 0-5 scale: where $0=$ no disease symptoms, $1=1-10 \%$ of the host surface covered by mycelia, $2=11-15 \%$ of the surface covered by mycelia, $3=26-50 \%$ of the surface covered by mycelia, $4=51-75 \%$ of the surface covered by mycelia, $5=$ more than $75 \%$ of the surface covered by mycelia. Disease index of every plant was determined, according to the mathematical formula: Disease Index $=\left\{\Sigma \mathrm{a} \times \mathrm{b} /\left(\mathrm{N}^{*} \mathrm{~K}\right)\right\} \times 100 \%$ Where $\mathrm{a}$ is the number of leaves with a corresponding infection degree, $b$ is the infection degree of leaves (scale differences from $0-5$ ), $\mathrm{N}$ is the total number of leaves counted in a plant, and $\mathrm{K}$ is the maximal value of lesion intensity ( $=5$ on the chosen scale) (Moradi et al 2017). To calculate sporulation, ten leaf discs (9 $\mathrm{mm}$ in diameter) were collected from the second true leaf for all treatments. Conidia were lightly brushed in $5 \mathrm{ml}$ ethanol (1\%). After that, the number of conidia was counted using hemocytometer and expressed as conidia per $\mathrm{cm}^{2}$ leaf tissue (Reuveni et al 2000). The experiment was duplicated and the collected data were obtained from one typical experiment trial.

Biochemical changes in cucumber plants during foliar application of chicken feather hydrolysate

\section{Extraction of plant crude enzymes}

After $48 \mathrm{~h}$ of foliar application, one gram of the second true leaves were collected and grounded using a mortar and pestle under cooling in $2 \mathrm{ml}$ extraction buffer composed of $(5 \mathrm{ml}$ of $1 \mathrm{M} \mathrm{Tris-HCl} \mathrm{pH}$ 7.5, $0.2 \mathrm{ml}$ of $0.5 \mathrm{M}$ EDTA, $0.87 \mathrm{~g}$ sodium chloride, $1 \mathrm{ml}$ of DMSO up to $100 \mathrm{ml}$ ). Grounded samples were centrifuged at $10000 \mathrm{rpm}$ for $10 \mathrm{~min}$. at $4^{\circ} \mathrm{C}$ (Conlon and Salter, 2007). The supernatant was transferred into new Eppendorf tubes to determine of peroxidase (POX), phenylalanine ammonia-lyase (PAL), polyphenol oxidase (PPO), and superoxide dismutase (SOD). All enzymes activities were recorded as unit/ mg protein by using apparatus UNICO 2100UV Spectrophotometer. Lowry method for protein concentration calculations were used and bovine serum albumin was the standard protein Lowry et al (1951).

\section{Peroxidase activity assay}

To determine peroxidase activity, $100 \mu$ of the crude enzyme extract were added to a reaction mixture consists of $2.9 \mathrm{ml}$ of sodium phosphate buffer (100 mM, pH 6.0) containing $0.25 \%(\mathrm{v} / \mathrm{v})$ guaiacol (2-methoxy-phenol) and $100 \mathrm{mM} \mathrm{H}_{2} \mathrm{O}_{2}$ to $100 \mu \mathrm{l}$ of the crude enzyme extract. O.D. at $470 \mathrm{~nm}$ per min was used to measure absorbance of color change (Hammerschmidt et al 1982).

\section{Phenylalanine ammonia-lyase activity assay}

To measure the phenylalanine ammonia-lyase (PAL) (EC 4.3.1.5) activity, a reaction mixture of 1.9 $\mathrm{ml}$ of $(0.05 \mathrm{M}, \mathrm{pH} 8.8)$ Tris- $\mathrm{HCl}$ buffer and $1 \mathrm{ml}$ of (20 mM) L-phenylalanine was prepared, then $100 \mu \mathrm{l}$ of the crude enzyme were added and incubated at $37^{\circ} \mathrm{C}$ for $1 \mathrm{~h} .0 .2 \mathrm{ml}$ of a freshly prepared $\mathrm{HCl}(6 \mathrm{M})$ was added to stop this reaction. Then, enzymatic activity was measured at $290 \mathrm{~nm}$ expressed as the $\mathrm{L}$-phenylalanine conversion rate to trans-cinnamic acid (Dickerson et al 1984).

\section{Polyphenol oxidase activity assay}

To test the activity of polyphenol oxidase (PPO), $100 \mu \mathrm{l}$ of the crude enzyme extract were added to a $3.0 \mathrm{ml}$ of a $0.01 \mathrm{M}$ freshly prepared buffered catechol solution to $0.1 \mathrm{M}$ phosphate buffer with $\mathrm{pH} 6.0$ ). Absorbance of color change was measured at 495 $\mathrm{nm}$ (Malik and Singh, 1980).

\section{Superoxide dismutase activity assay}

To detect the superoxide dismutase activity, 200 $\mu \mathrm{l}$ of the crude enzyme extract were added to $3 \mathrm{ml}$ of the prepared reaction mixture contained phosphate buffer (50 mM, pH 7.8), methionine (13 mM), nitro blue tetrazolium $(75 \mu \mathrm{M})$, EDTA $(100 \mathrm{mM})$ then, the addition of $2 \mu \mathrm{M}$ riboflavin as the last ingredient in test tubes. All tubes were incubated under shaker of $100 \mathrm{rpm}$ under light conditions for 10 minutes. After that, all tubes were covered with a black cloth to stop the reaction. Absorbance of the all reactions was read at $560 \mathrm{~nm}$. (Robert et al 1980).

\section{Statistical analysis}

ANOVA with post hoc multiple comparisons using Tukey's HSD was analyzed to all data obtained from the all above experiments. For shake flask experiment trials, comparison of three replicates mean was calculated using SPSS 26.0 for windows at a significance level of $p<0.05$. 


\section{Optimization of Amino Acid Production from Chicken Feather by Bacillus Amyloliquefaciens Using Response Surface Methodology as a New Tool for Powdery Mildew Disease Biocontrol}

\section{RESULTS AND DISCUSSION}

\section{Statistical screening of significant media com- ponents by Plackett-Burman Design (PBD)}

Six nutritional and five physical factors (feather, glucose, yeast extract, peptone, $\mathrm{CaCO}_{3}, \mathrm{KH}_{2} \mathrm{PO}_{4}$, temp., $\mathrm{pH}$, inoculum size, agitation rate and incubation time) were analyzed by PBD for their effects on amino acids production. Amino acids reached the highest production level at ratio of $2.1 \mathrm{~g} / \mathrm{l}$ at run 7 which composed of (feather $20 \mathrm{~g} / \mathrm{l}, 0 \mathrm{~g} / \mathrm{l}$ of glucose, yeast extract and peptone, $10 \mathrm{~g} / \mathrm{l}$ of $\mathrm{CaCO} 3,0.2$ of $\mathrm{KH}_{2} \mathrm{PO}_{4}$, incubated at $42^{\circ} \mathrm{C}$ at agitation rate of 200 $\mathrm{rpm}$ and inoculated with $2 \%$ of the standard inoculum. Fig. 1 showed the main effects plot which is conjugated with ANOVA analysis to determine the level mean differences for all factors. The produced amino acids mean for each factor level was connected by a line. Factors with horizontal line parallel to the $X$ axis are not main effects. However, factors with not horizontal line are considered as main effect factors. So, feather, yeast extract, $\mathrm{CaCO}_{3}$, $\mathrm{KH}_{2} \mathrm{PO}_{4}$ and agitation rate are significant main effects for the amino acids production. ANOVA resulted that "Model $F$-value" equals to 26.4 and low probability value $<0.0500$ (Prob. $>$ F) indicated that the navigated model was significant. The variable parameters, revealing statistically remarkable significant results, were screened. Factors, revealing values of less than 0.05 (Prob. $>F$ ) which affected the response significantly were feather, yeast extract, $\mathrm{CaCO}_{3}, \mathrm{KH}_{2} \mathrm{PO}_{4}$ and agitation rate as illustrated. Regression coefficient results showed that all process variables positively affect the amino acids production. However, effect of glucose, peptone, temp., $\mathrm{pH}$, inoculum size and incubation time contribution was negligible. Therefore, these ingredients were avoided in the next step of optimization. Out of the significant media components, feather, yeast extract, $\mathrm{CaCO}_{3}, \mathrm{KH}_{2} \mathrm{PO}_{4}$ and agitation rate, with confidence level $95 \%$, were further optimized by CCD.
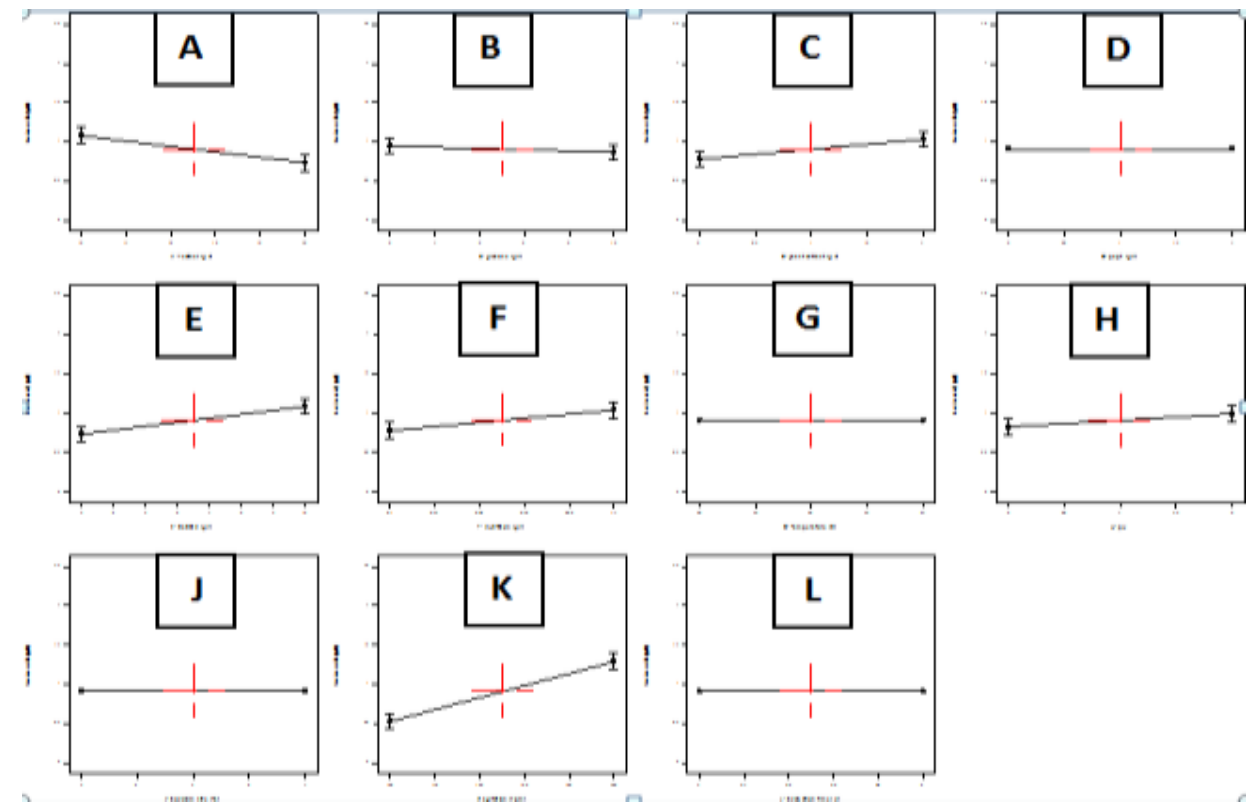

Fig 1. Main effects plot of PBD indicating that (feather: $A$, yeast extract: $\mathrm{C}, \mathrm{CaCO}_{3}$ : $\mathrm{E}, \mathrm{KH}_{2} \mathrm{PO}_{4}$ : $\mathrm{F}$ and agitation speed: K) are the main significant media components affecting amino acid production by Bacillus amyloliquifaciens $35 \mathrm{~s}$ 
Central composite design (CCD) for optimization of medium components

The CCD statistical design tool using RSM was performed to study the singular and interactive effects of different process parameters on amino acids production by $B$. amyloliquefaciens. Table 5 summarizes amino acids production of CCD experiment for each individual run along with the predicted response. Analysis of variance (ANOVA) was calculated to obtain the regression equation of the produced amino acids in which amino acids production $(Y)=-142.21571+12.98718$ feather +44.24693 yeast extract $+5.56997 \mathrm{CaCO}_{3}+78.35570 \mathrm{KH}_{2} \mathrm{PO}_{4}+$ 0.786464 agitation +0.064500 feather * yeast extract-0.040571 feather ${ }^{*} \mathrm{CaCO}_{3}-0.465000$ feather * $\mathrm{KH}_{2} \mathrm{PO}_{4}-0.001845$ feather * agitation- 0.032500 yeast extract * $\mathrm{CaCO}_{3}-3.08333$ yeast extract * $\mathrm{KH}_{2} \mathrm{PO}_{4}-0.021650$ yeast extract * agitation + $1.42857 \mathrm{CaCO}_{3}{ }^{*} \mathrm{KH}_{2} \mathrm{PO}_{4}+0.005200 \mathrm{CaCO} 3{ }^{*} \mathrm{ag}-$ itation + $0.013167 \mathrm{KH}_{2} \mathrm{PO}_{4}$ * agitation - 0.395855 feather ${ }^{2}-6.04386$ yeast extract ${ }^{2}-0.507662 \mathrm{CaCO}_{3}{ }^{2}$ - $16.17172 \mathrm{KH}_{2} \mathrm{PO}_{4}{ }^{2}$ - 0.002195 agitation ${ }^{2}$. Model analysis of ANOVA was calculated as follows: the model $F$-value was 15.23 . High model $F$-value with a very low probability value $[($ Prob. $>F)$ less than $0.0001]$ indicated that the selected model was highly significant. The linear terms $C, E, A^{2}, B^{2}, C^{2}$, $\mathrm{E}^{2}$ of the model were significant in which (Prob.> $\mathrm{F}$ less than 0.0500). The value of multiple correlation determination coefficients $R^{2}$ was 0.9018 which explains $90.18 \%$ of the response variations. The model showed coefficient of variation (CV), standard deviation, mean and predicted residual sum of squares (PRESS) values of $9.69 \% 4.35,44.91$ respectively. For this model, the 'lack of fit' was found to be "not significant".

The software Design-Expert suggested solution runs based on the data generated with values lower and higher than the low and high levels of each factor for decreasing the experimental error. Table 6 listed the observed optimum values of growth medium parameters and predicted response of the selected solution. The model regression equations were represented by using 3D surface graphs and $2 \mathrm{D}$ contour lines to represent the regression equation. These results showed that amino acids promotion conditions were different from those enhanced cell growth (Venugoal and Saramma, 2006).

In the present work, based on RSM study, various physical parameters and media components showed to have significant effects on amino acids production. Analysis of physical parameters indicated that production of amino acids by $B$. amyloliquefaciens is non-growth dependent. These results were previously observed by of Genckal and Tari (2006) Different variables yield were predicted from the respective response surface plots (Fig. 2 A-C). Maximum level factors concentrations for maximum amino acids production was plotted using three dimensional (3D) response surface curves. Fig 2 shows the relative effects of five different sets of factors, feather and yeast extract $(\mathrm{A})$, feather and $\mathrm{CaCO}_{3}(\mathrm{~B})$, yeast extract and agitation (C), without change in the other factors' levels. Results clearly showed a strong degree of curvature of 3D surface, from where the optimum was determined. Model validation was done experimentally using CCD model for medium components. Model validation was verified as the actual and predicted values of $6.55 \mathrm{~g} / \mathrm{l}, 6.60 \mathrm{~g} / \mathrm{l}$, respectively (as illustrated in Table 6).

Free amino acids content from hydrolyzed chicken feathers by amino acid analyzer

Release of free-amino acids in the modified medium inoculated with $B$. amyloliquifaciens $35 \mathrm{~s}$ showed that there was an increase in the release of free amino acids (valine, glycine, leucine and thereonine) from the chicken-feathers as illustrated in Fig. 3. Amino acids were recovered through amino acid analyzer from the feather-hydrolysate in the following order: aspergine, therionine, serine, glutamine, proline, glycine, alanine, cysteine, valine, methionine, isoleucine, leucine, tyrosine, phenylalanine, histidine, lysine, and arginine. 

Amyloliquefaciens Using Response Surface Methodology as a New Tool for Powdery Mildew Disease Biocontrol

Table 5. Central composite design (CCD) of the three independent medium components with the observed and predicated values of produced amino acids

\begin{tabular}{|c|c|c|c|c|c|c|c|}
\hline $\begin{array}{l}\text { Run } \\
\text { Order }\end{array}$ & $\begin{array}{c}(\mathrm{A}) \\
\text { Feather } \\
(\mathrm{g} / \mathrm{l})\end{array}$ & $\begin{array}{c}(\mathrm{B}) \\
\text { yeast extract } \\
(\mathrm{g} / \mathrm{l}) \\
\end{array}$ & $\begin{array}{c}(\mathrm{C}) \\
\mathrm{CaCO}{ }_{3} \\
(\mathrm{~g} / \mathrm{l})\end{array}$ & $\begin{array}{c}(\mathrm{D}) \\
\mathrm{KH}_{2} \mathrm{PO}_{4} \\
(\mathrm{~g} / \mathrm{l}) \\
\end{array}$ & $\begin{array}{c}\text { (E) } \\
\text { Agitation } \\
(\mathrm{rpm})\end{array}$ & $\begin{array}{c}\text { Actual } \\
\text { Value } \\
\text { (g/l) }\end{array}$ & $\begin{array}{l}\text { Predicted } \\
\text { Value } \\
\text { (g/l) }\end{array}$ \\
\hline 1 & 15 & 3 & 0 & 1.35 & 150 & 3.54 & 3.63 \\
\hline 2 & 20 & 2 & 10 & 1.5 & 100 & 3.58 & 3.66 \\
\hline 3 & 20 & 4 & 10 & 1.2 & 100 & 3.07 & 2.78 \\
\hline 4 & 15 & 3 & 6.5 & 1.35 & 50 & 3.16 & 3.03 \\
\hline 5 & 20 & 4 & 3 & 1.2 & 200 & 4.33 & 4.69 \\
\hline 6 & 20 & 2 & 3 & 1.5 & 200 & 6.50 & 6.60 \\
\hline 7 & 15 & 3 & 6.5 & 1.65 & 150 & 2.57 & 2.51 \\
\hline 8 & 15 & 3 & 6.5 & 1.35 & 150 & 6.55 & 6.60 \\
\hline 9 & 15 & 3 & 6.5 & 1.35 & 150 & 4.22 & 4.56 \\
\hline 10 & 20 & 4 & 3 & 1.5 & 100 & 6.55 & 6.60 \\
\hline 11 & 15 & 3 & 6.5 & 1.35 & 150 & 6.02 & 5.28 \\
\hline 12 & 10 & 4 & 3 & 1.2 & 100 & 4.69 & 4.45 \\
\hline 13 & 15 & 3 & 13.5 & 1.35 & 150 & 3.82 & 3.84 \\
\hline 14 & 20 & 2 & 10 & 1.2 & 200 & 4.04 & 4.42 \\
\hline 15 & 10 & 4 & 10 & 1.5 & 100 & 5.43 & 4.80 \\
\hline 16 & 15 & 5 & 6.5 & 1.35 & 150 & 3.35 & 3.19 \\
\hline 17 & 15 & 3 & 6.5 & 1.35 & 250 & 6.55 & 6.60 \\
\hline 18 & 15 & 3 & 6.5 & 1.35 & 150 & 3.58 & 3.44 \\
\hline 19 & 10 & 4 & 10 & 1.2 & 200 & 6.55 & 6.60 \\
\hline 20 & 15 & 3 & 6.5 & 1.35 & 150 & 6.55 & 6.60 \\
\hline 21 & 5 & 3 & 6.5 & 1.35 & 150 & 6.55 & 6.45 \\
\hline 22 & 15 & 3 & 6.5 & 1.35 & 150 & 3.69 & 3.80 \\
\hline 23 & 20 & 4 & 10 & 1.5 & 200 & 3.87 & 4.05 \\
\hline 24 & 20 & 2 & 3 & 1.2 & 100 & 3.16 & 3.54 \\
\hline 25 & 25 & 3 & 6.5 & 1.35 & 150 & 3.75 & 3.88 \\
\hline 26 & 10 & 4 & 3 & 1.5 & 200 & 3.44 & 3.49 \\
\hline 27 & 10 & 2 & 3 & 1.2 & 200 & 3.54 & 3.63 \\
\hline 28 & 15 & 3 & 6.5 & 1.05 & 150 & 3.58 & 3.66 \\
\hline 29 & 15 & 1 & 6.5 & 1.35 & 150 & 3.07 & 2.78 \\
\hline 30 & 10 & 2 & 3 & 1.5 & 100 & 3.16 & 3.03 \\
\hline 31 & 10 & 2 & 10 & 1.5 & 200 & 4.33 & 4.69 \\
\hline
\end{tabular}


Table 6. Validation for the CCD model of medium components for optimized amino acids production by $B$. amyloliquefaciens 35s from chicken feather hydrolysate

\begin{tabular}{|c|c|c|c|c|c|}
\hline $\begin{array}{l}\text { Production parameters } \\
\text { (and their levels) }\end{array}$ & $\begin{array}{c}\text { Actual } \\
\text { value } \\
(\mathrm{g} / \mathrm{l})\end{array}$ & $\begin{array}{l}\text { Predicted } \\
\text { value } \\
(\mathrm{g} / \mathrm{l})\end{array}$ & $\begin{array}{c}\text { Biomass } \\
(\mathrm{g} / \mathrm{l})\end{array}$ & $\begin{array}{l}\text { Productivity } \\
\left(\mathrm{gl}^{-1} \mathrm{~h}^{-1}\right)\end{array}$ & $\begin{array}{l}\text { Productivity yield } \\
\text { coefficient relative } \\
\text { to biomass } \\
(\%)\end{array}$ \\
\hline $\begin{array}{c}\text { Feather }(15 \mathrm{~g} / \mathrm{l}) \\
\text { Yeast extract }(3 \mathrm{~g} / \mathrm{l}) \\
\mathrm{CaCO}_{3}(6.5 \mathrm{~g} / \mathrm{l}) \\
\mathrm{KH}_{2} \mathrm{PO}_{4}(1.35 \mathrm{~g} / \mathrm{l}) \\
\text { Agitation }(150 \mathrm{rpm})\end{array}$ & 6.55 & 6.60 & 14 & 0.27 & 46.78 \\
\hline
\end{tabular}

Productivity $(\mathrm{P})=$ Amount of amino acids produced $\left(\mathrm{gl}^{-1}\right) /$ fermentation time $(\mathrm{h})=\mathrm{gl}^{-1} \mathrm{~h}^{-1}$. Amino acids yield coefficient relative to biomass $\left(\mathrm{Y}_{\mathrm{p} / \mathrm{x}}\right)(\%)=$ Amount of amino acids produced $\left(\mathrm{gl}^{-1}\right) /$ amount of biomass $\left(\mathrm{gl}^{-1}\right){ }^{*} 100$.
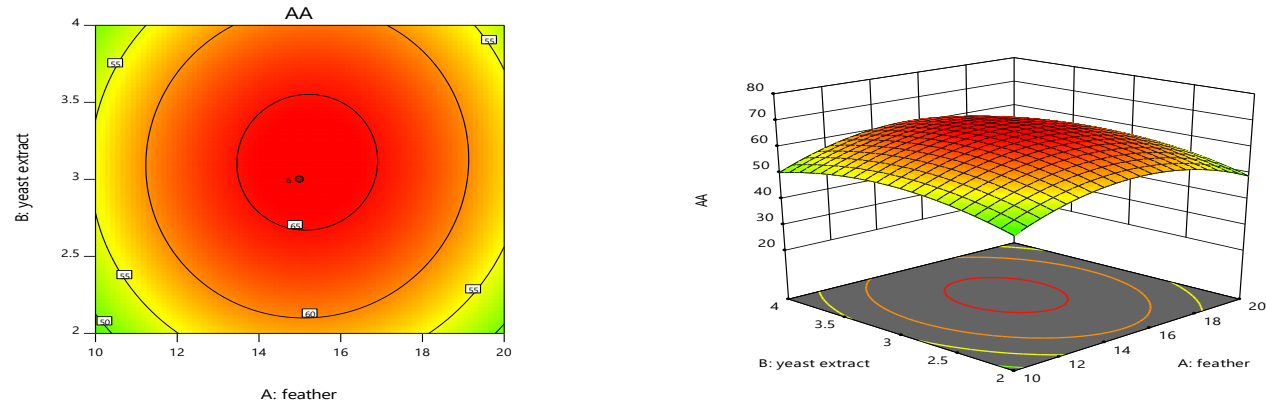

(A) Contour and response surface plots showing the relative effects of feather and yeast extract on the production of amino acids.
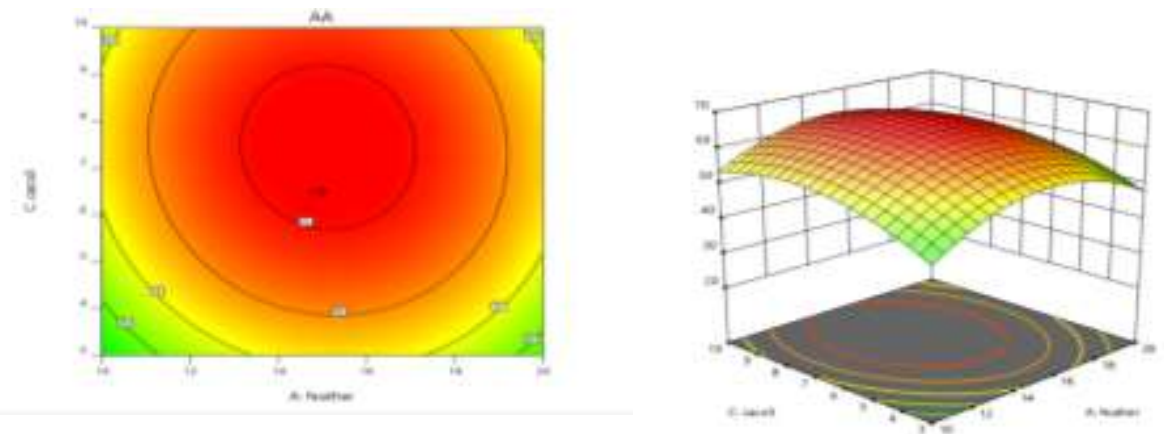

(B) Contour and response surface plots showing the relative effects of feather and $\mathrm{CaCO}_{3}$ on the production of amino acids 

Tool for Powdery Mildew Disease Biocontrol
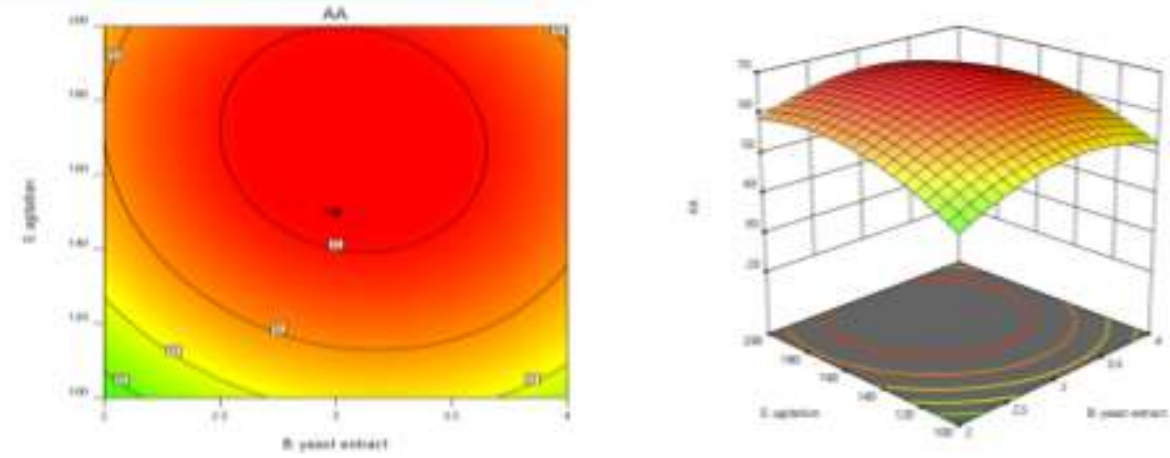

(C) Contour and response surface plots illustrating the effects of yeast extract and agitation on the production of amino acids.

Fig. 2A-C. The two-dimensional contour plots and three-dimensional response surface plots showing the effect of nutritional factors and their mutual interactions on amino acids production by Bacillus amyloliquifaciens 35s.

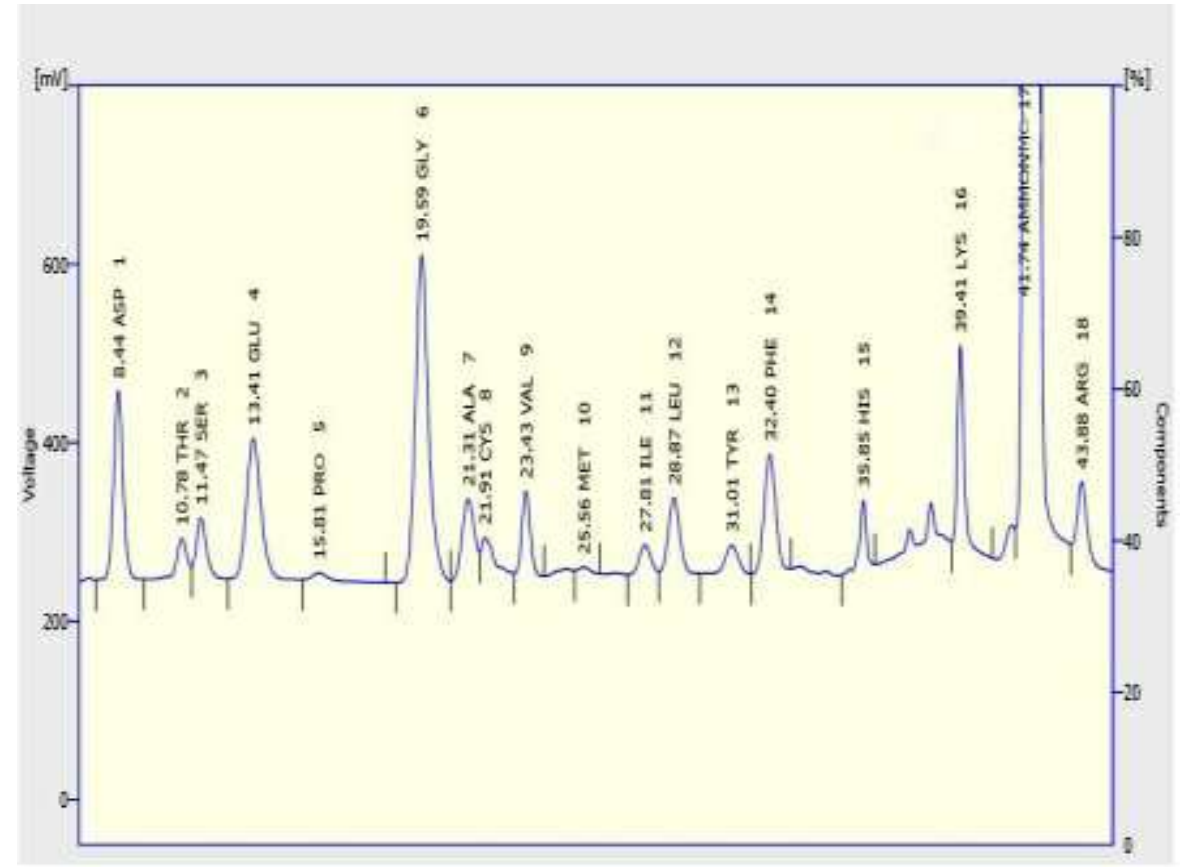




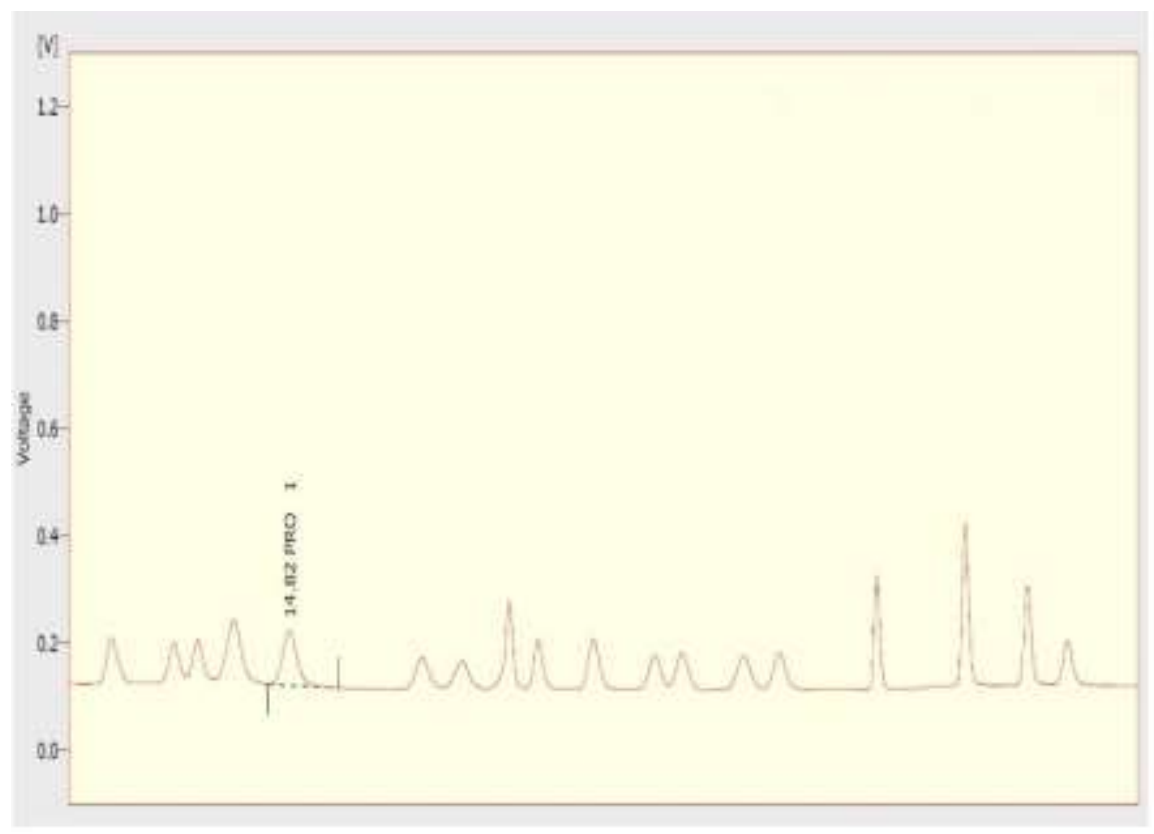

Fig. 3. Amino acids composition of chicken feather hydrolysate by automatic amino acid analyzer (Sykam SW) using LC AKO6 Na -24050313 column

Effect of chicken feather hydrolysate as foliar application on cucumber plants against $\boldsymbol{P}$. xanthii the causing of powdery mildew disease

Foliar application using different concentrations $(0,5,10,15$ and $20 \%)$ of chicken feather hydrolysate were applied on cucumber plants post $24 \mathrm{~h}$. of infected plants with $P$. xanthii. Disease index was estimated on every plant. All concentrations of chicken feather hydrolysate showed significant effect on reducing disease index. The lowest concentration $5 \%$ was the lowest impact on disease. On the other hand, the higher concentration $20 \%$ showed the best effect on disease reduction compared with control plants. Extra foliar application was performed 13 days after inoculation showed a decrease in disease index for all concentrations compared with control plants (Fig. 4, 5).

Also, all applied chicken feather hydrolysate concentrations led to a significant reduction in the number of conidia produced when compared to the control plants for both first and second foliar application treatments (Fig. 6). The mechanism by which this occurs is unknown possibly. However, amino acids contained in chicken feather hydrolysate might be effective in suppressing the disease. It could be concluded that chicken feathers have valuable source of natural amino acids which induced plant resistance against powdery mildew by increasing of antioxidant enzyme activity (Moradi et al 2017).

The results obtained reveal that foliar applications with higher amino acids concentrations from chicken feathers stimulated enzyme activities i.e., peroxidase (POX), phenylalanine ammonia-lyase (PAL), polyphenol oxidase (PPO) and superoxide dismutase (SOD).

Data illustrated in Fig. 7 clearly indicate that there was direct relationship between POX activity and foliar concentration ranging between $10-20 \%$ Induction of POX may serve as a defense mechanism against powdery mildew disease as it contributes the exploitation of $\mathrm{H}_{2} \mathrm{O}_{2}$ in lignification of cells under both normal and stress conditions. Peroxidases (POX) catalyze many important biological processes of plant - defense mechanisms (Gupta et al 2015) as they play a significance role in strengthen of cell wall structures by catalyzing the suberin polymerization, and lignin biosynthesis. Plant peroxidases also facilitate the formation of diferulic acid linkages and production of hydroxyl radical (Almagro et al 2009).

Data presented in Figs. 8, 9 and 10 illustrated that all concentrations of foliar chicken feather hydrolysate $(5,10,15$, and $20 \%$ ) stimulated significantly enzyme activities of PAL, PPO, and SOD 


\section{Optimization of Amino Acid Production from Chicken Feather by Bacillus Amyloliquefaciens Using Response Surface Methodology as a New Tool for Powdery Mildew Disease Biocontrol}

compared with untreated plants. The highest enzymatic activity was observed at concentration $20 \%$ of chicken feather hydrolysate. Phenylalanine ammonia-lyase (PAL) plays an important role as the key enzyme in phenol biosynthesis. It helps in plant resistance induction against different stress conditions through the regulation of phenolic compounds' biosynthesis (Wen et al 2005). Phenylalanine ammonia-lyase converts phenylalanine to trans-cinnmaic acid which in turn modified by other enzymes resulting in phenolics including phytoalexins (Singh and Prithiviraj, 1997). Also, PAL activity is induced by several factors such as pathogen ingress, insect damage and abiotic stress.

Polyphenol oxidases (PPO) catalyses the o-hydrolxylation of monophenols to o-quinones, which rapidly polymerized to produce black or brown pigments (polyphenols). In healthy tissue, PPO are found in plastids and are responsible for tissue darkening symptom during lesion formation (Vaughn and Duke, 1984). Their role is to limit secondary infection and the further spreading of pathogens by sealing off wounds or infected tissues. The oxidation of polyphenol by PPO formed a brown colored melanin which inhibits the growth of mildew disease. Plant PPOs oxidize polyphenols into antimicrobial quinones. Quinones are known to play an important role in lignifications of plant cell wall during pathogen's attack (Tran et al 2012).

SOD is the first line of defense in plants by catalyzing superoxide anion radicles dismutation into hydrogen peroxide and molecular oxygen. Moreover, SOD induction reduces the cellular damage caused by oxidative stress (Sunkar et al 2006).

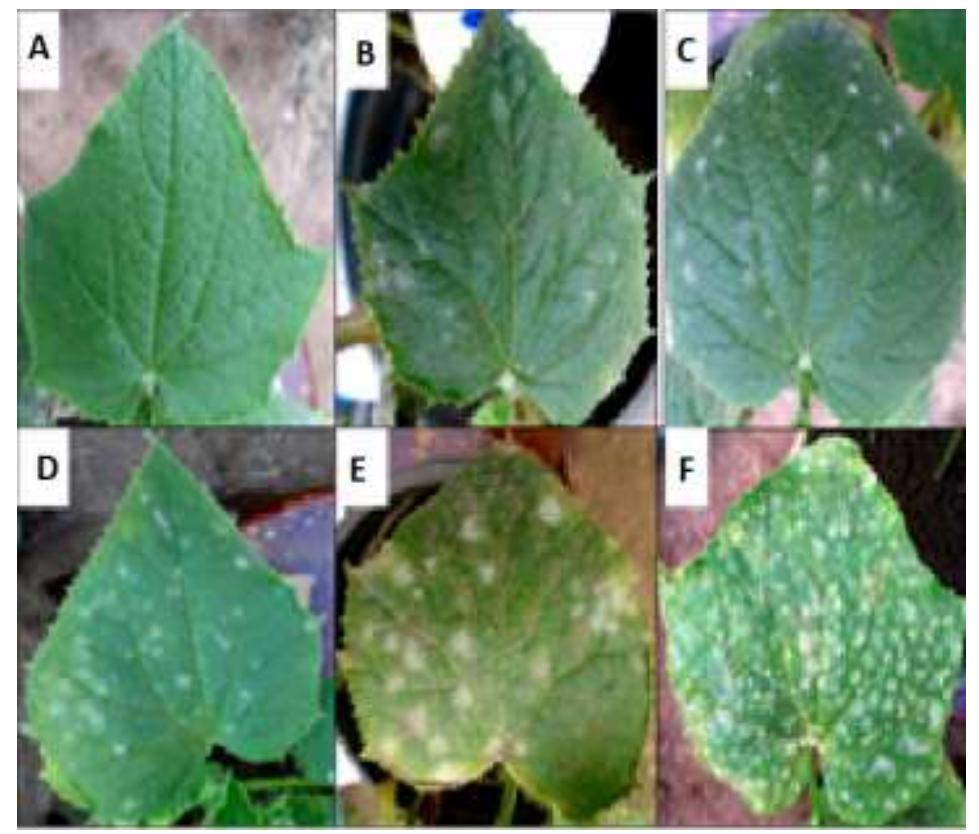

Fig. 4. Comparison of cucumber leaves treated with chicken feather hydrolysate against powdery mildew 20 days after inoculation with $P$. xanthii. (A): healthy leaf. (B): cucumber leave exposed to $20 \%$ chicken feather hydrolysate. (C): cucumber leave with $15 \%$ chicken feather hydrolysate, (D): cucumber leave with $10 \%$ chicken feather hydrolysate. (E): cucumber leave with 5\% chicken feather hydrolysate $(F)$ : control. Photos were taken on the second true leaf of all concentrations. 


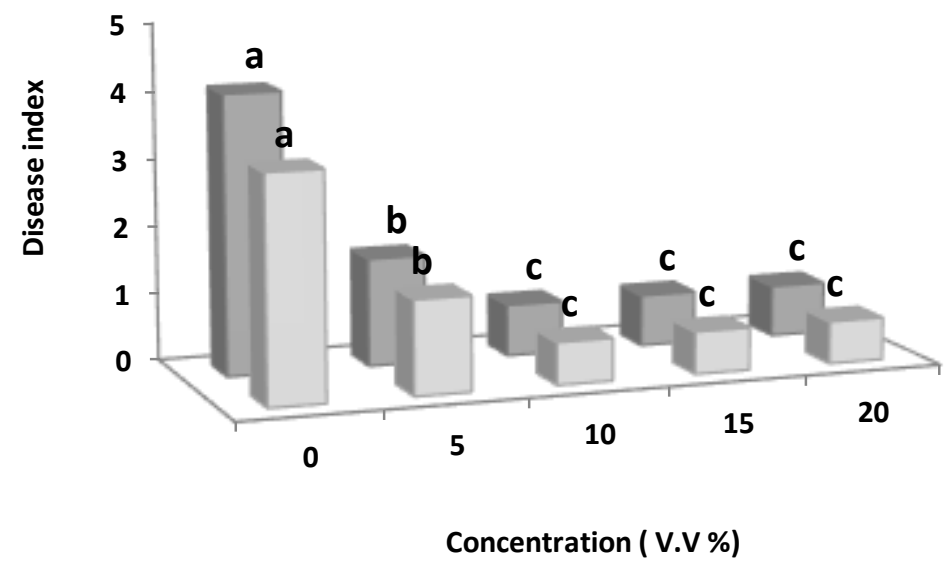

Fig. 5. Effect of foliar application of chicken feather hydrolysate concentrations on disease index of cucumber powdery mildew disease. Same letters show non-significant means.

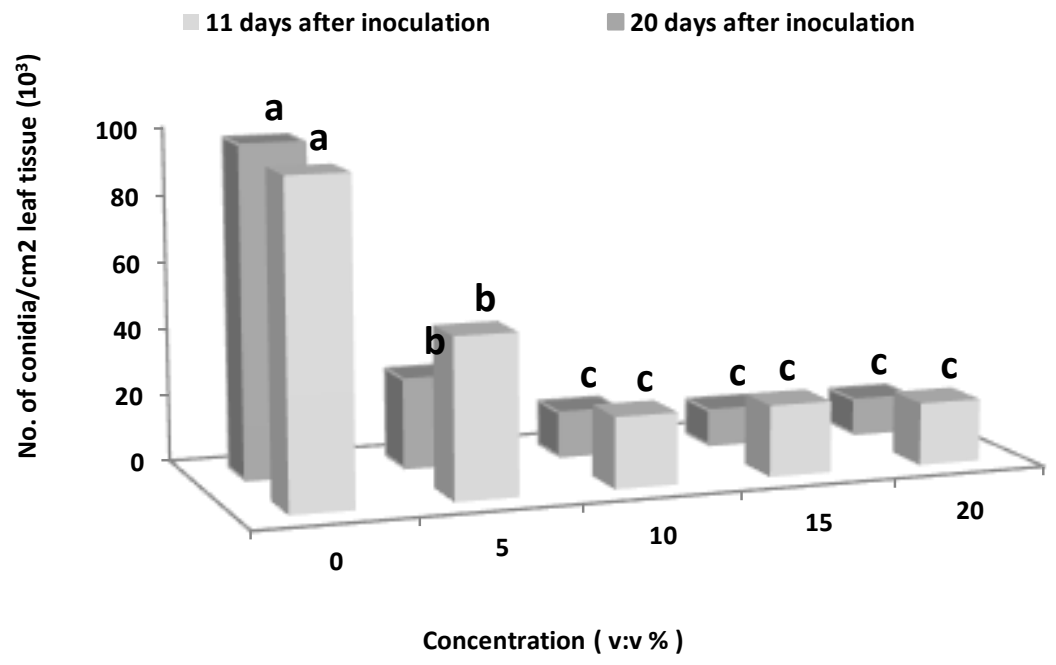

Fig. 6. Effect of foliar application of chicken feather hydrolysate concentrations on sporulation of $P$. xanthii on second true leaf of cucumber plant. same letters show non-significant means. 


\section{Tool for Powdery Mildew Disease Biocontrol}

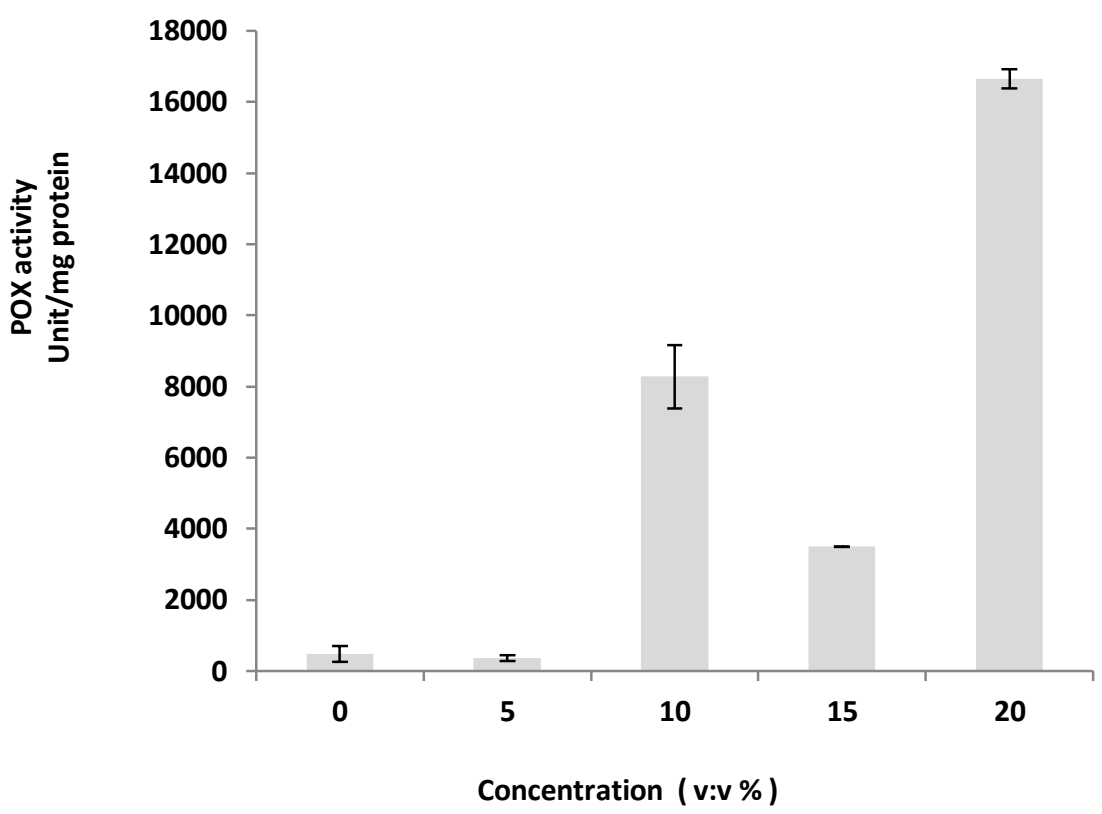

Fig. 7. Effect of foliar application of chicken feather hydrolysate concentrations on peroxidase activity of the second true leaf after $24 \mathrm{~h}$. of inoculation.

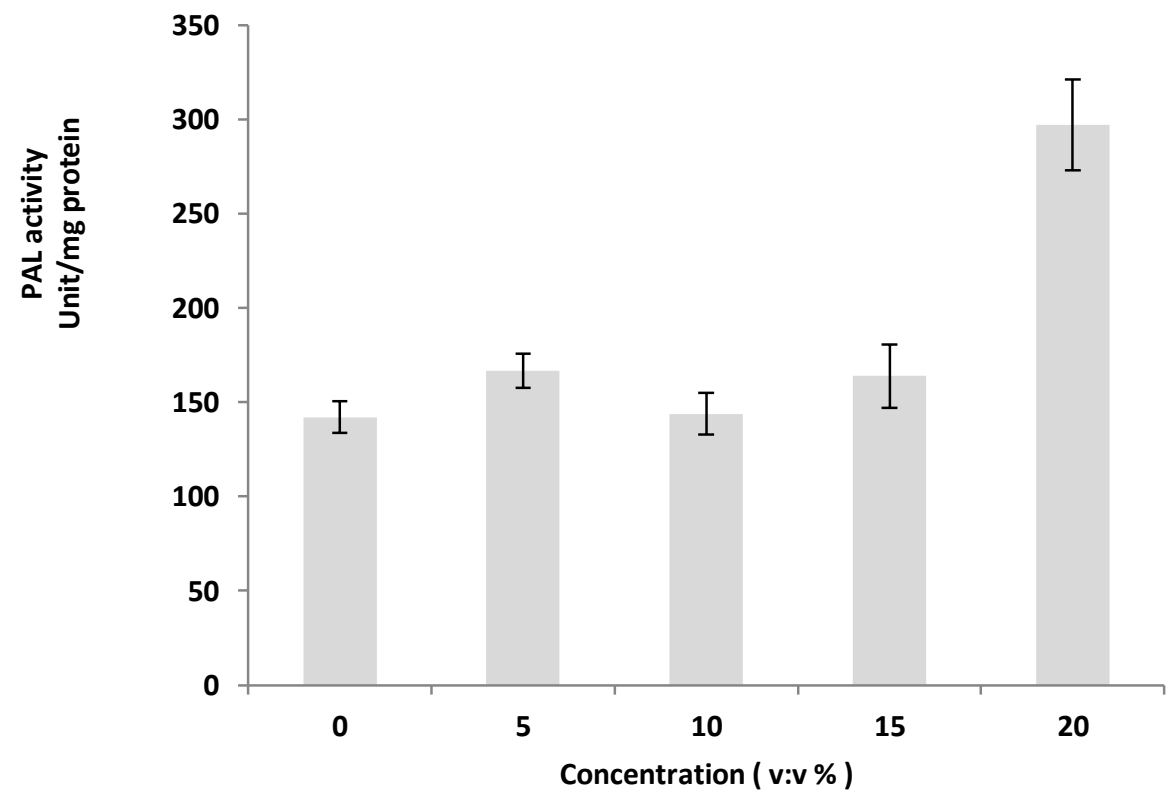

Fig. 8. Effect of foliar application of chicken feather hydrolysate concentrations on phenylalanine ammonia-lyase activity of the second true leaf after $24 \mathrm{~h}$. of inoculation. 


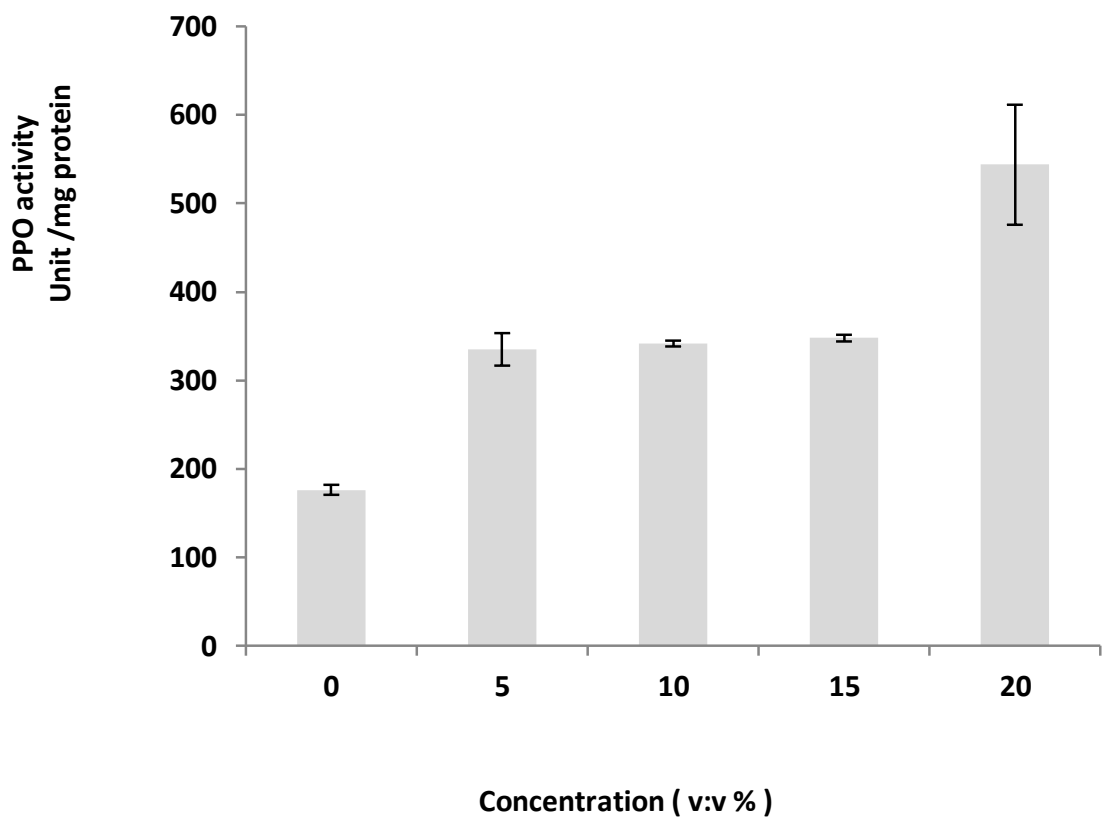

Fig. 9. Effect of foliar application of chicken feather hydrolysate concentrations on polyphenol oxidase activity of the second true leaf after $24 \mathrm{~h}$. of inoculation.

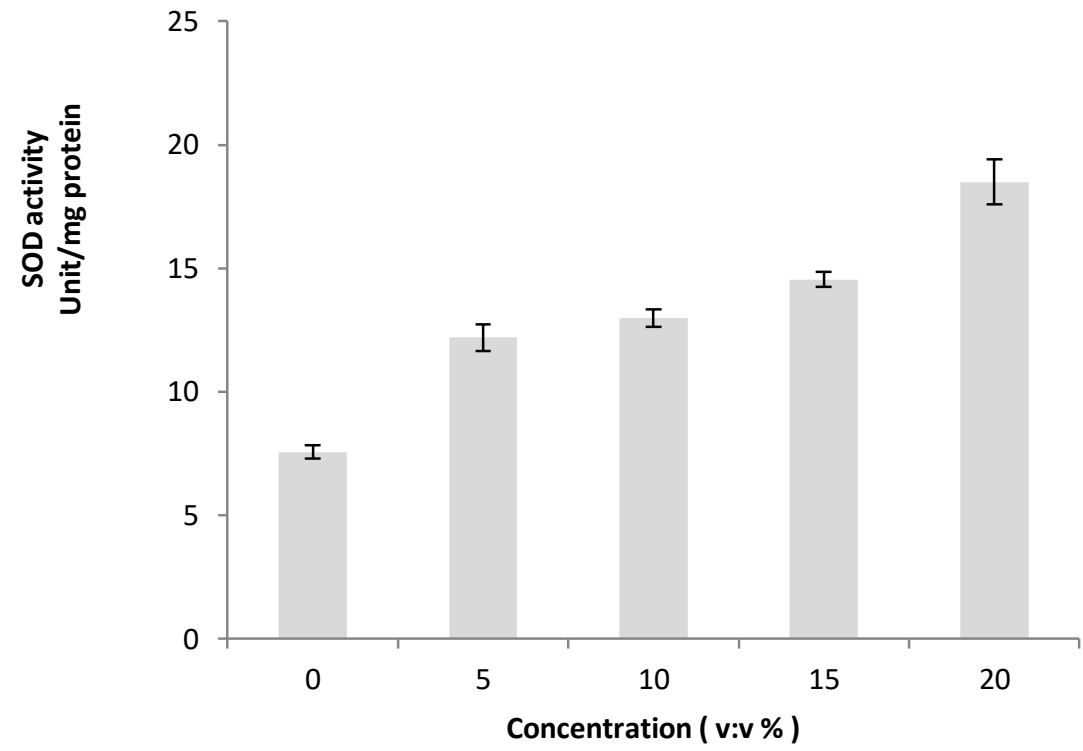

Fig. 10. Effect of foliar application of chicken feather hydrolysate concentrations on superoxide dismutase activity of the second true leaf after $24 \mathrm{~h}$. of inoculation. 


\section{Optimization of Amino Acid Production from Chicken Feather by Bacillus Amyloliquefaciens Using Response Surface Methodology as a New Tool for Powdery Mildew Disease Biocontrol}

\section{CONCLUSION}

In this study, response surface methodology, as statistical approach, showed to be more adequate and efficient for the optimization amino acids production from chicken feather hydrolysate by Bacillus amyloliquefaciens 35s. Experimental analysis increased the amino acid production from $2.1 \mathrm{~g} / \mathrm{l}$ in PBD by 3.1 times to reach $6.55 \mathrm{~g} / \mathrm{l}$. Amino acids analysis was performed using automated amino acid analyzer. Data showed the release of asparagine, threonine, serine, glutamine, proline, glycine, alanine, cysteine, valine, methionine, isoleucine, leucine, tyrosine, phenyl alanine, histidine, lysine and arginine, respectively. Foliar application of cucumber leaves with feather chicken hydrolysate led to a significant increase in POX, PAL, PPO and SOD enzymatic activities as an indicator for a significant increase in the induced resistance of cucumber leaves against powdery mildew.

\section{ACKNOWLEDGEMENT}

The authors would like to thank Dr. Ahmed A Abdelhafez for his continuous encouragement and providing advice to finalize this project.

\section{REFERENCES}

Almagro L.; Gómez Ros L.V.; Belchi-Navarro S.; Bru R.; Ros Barceló A. and Pedreño M.A (2009). Class III peroxidases in plant defence reactions. J. Exp. Bot., 60, 377-390.

Anson M.L. (1938). The estimation of pepsin, trypsin, papain and cathepsin with hemoglobin. $\mathbf{J}$. Gen. Physiol. 22, 79-89.

Bahadur A.; Singh D.P.; Sarma B.K.; Singh U.P. (2012). Foliar application of L-phenylalanine and ferulic acids to pea plants: induced phenylalanine ammonia-lyase activity and resistance against Erysiphe pisi. Arch Phytopathol. Plant Protec. 45, 398-403.

Box G.E.P. and Wilson K.B. (1951). On the experimental attainment of optimum conditions. J. Royal Statist Soc. 13, 1-45.

Chauhan B. and Gupta R. (2004). Application of statistical experimental design for optimization of alkaline protease production from Bacillus $\mathrm{sp}$ RGR-14. Proc. Biochem. 39, 2115-2122.

Conlon H.E. and Salter M.G. (2007). Plant protein extraction. Methods Mol. Biol., 362, 379-383.
Cosme B.; Josefina L.F.; Raul A.M.; Maria M.; Armando C.F.J.; Benigno V.T.J.; Fabiola L.S. and Saul G.R. (2012). Characterization of powdery mildew in cucumber plants under greenhouse conditions in the Culiacan Valley, Sinaloa, Mexico. Afr. J. Agric. Res., 7, 3237-3248.

D'Este M.; Alvarado-Morales M. and Angelidaki I. (2018). Amino acids production focusing on fermentation technologies-A review. Biotechnol Adv 36, 14-25.

Dickerson D.P.; Pascholati S.F.; Hagerman A.E.; Butler L.G. and Nicholson R.L. (1984). Phenylalanine ammonia-lyase and hydroxy cinnamate: CoA ligase in maize mesocotyls inoculated with Helminthosporium maydis or Helminthosporium carbonum. Physiol. Plant Pathol., 25, 111-123.

Dik A.J.; Gaag D.J.V.D.; Pijnakker J. and Wubben J.P. (2004). Integrated control strategies for all pests and diseases in several glasshouse crops and implementation in practice. Bulletin OILB/SROP 27, 35-39.

Genckal H.D. and Tari C. (2006). Alkaline protease production from alkalophilic Bacillus sp. isolated from natural habitats. Enzyme Microbial Technol 39, 703-710.

Gupta D.K.; Palma J.M. and Corpas F.J. (2015). Reactive oxygen species and oxidative damage in plants under stress, Heidelberg, Germany: Springer, pp. 1-22.

Hammerschmidt R.; Nuckles E.M. and Kuc J. (1982). Association of enhanced peroxidase activity with induced systemic resistance of cucumber to Colletotrichum lagenarium. Physiol. Plant Pathol. 20, 73-82.

Hasabi, V.; Askari, H.; Alavi, S.M. and Zamanizadeh, H. (2014). Effect of amino acid application on induced resistance against citrus canker disease in lime plants. J. Plant Protec. Res., 54, 144-149.

Joo H.S. and Chang C.S. (2006). Oxidant and SDS-stable alkaline protease from a halo-tolerant Bacillus clausii 1-52: enhanced production and simple purification. J. Appl. Microbiol., 98, 491-497.

Lassoued I.; Mora L.; Barkia A.; Aristoy M.C.; Nasri M. and Toldra F. (2015). Bioactive peptides identified in thornback ray skin's gelatin hydrolysates by proteases from Bacillus subtilis and Bacillus amyloliquefaciens. J. Proteomics 128, 8-17. 
Lowry O.H.; Rosebrough N.J.; Farr A.L. and Randall R.J. (1951). Protein measurment with the Folin phenol reagent. J. Biol. Chem., 193, 265-275.

Malik C.P. and Singh M.B. (1980). Plant enzymology and histo enzymology. Kalyani Publishers, lundhiana and Printed in Navin Shahdara, Delhi, pp. 54-56.

McGrath M.T. (1996). Successful management of powdery mildew in pumpkin with disease threshold-based fungicide programs. Plant Dis., 80, 910-916.

Moradi N.; Rahimian H.; Dehestani A. and Babaeizad V. (2017). Comparative study of selected cucumber cultivars resistant to powdery mildew caused by Sphaerotheca fuliginea. Plant Cell Biotechnol. Mol. Biol. 18, 30-38.

Nassar F.R.; Abdelhafez A.A.; El-Tayeb T.S. and Samah H. Abu-Hussein (2015). Purification, characterization and applications of proteases produced by Bacillus amyloliquefaciens 35s isolated from soil of the Nile Delta of Egypt. British Microbiology Research Journal 6, 286-302.

Rankovic B. (2003). Powdery mildew fungi (order Erysiphales) on plants in Montenegro (Chernogoria). Mycol. Phytopathol. 37, 42-52.

Reddy L.V.A.; Wee Y.J. and Ryu H.W. (2008). Purification and characterization of an organic solvent and detergent-tolerant novel protease produced by Bacillus sp. RKY3. J. Chem. Technol. Biotechnol., 83, 1526-1533.

Reuveni M.; Agapov V. and Reuveni R. (1996). Controlling powdery mildew caused by Sphaerotheca fuliginea in cucumber by foliar sprays of phosphate and potassium salts. Crop Prot., 15, 49-53.

Reuveni R.; Dor G.; Raviv M.; Reuveni M. and Tuzun S. (2000). Systemic resistance against Sphaerotheca fuliginea in cucumber plants exposed to phosphate in hydroponics system and its control by foliar spray of mono potassium phosphate. Crop Prot., 19, 355-361.

Robert R.; Stewart C. and Bewley J.D. (1980). Lipid peroxidation associated with accelerated aging of soybean axes. Plant Physiol., 65, 245248.
Singh U.P. and Prithiviraj B. (1997). Neemazal, a product of neem (Azadirachta indica), induces resistance in pea (Pisum sativum) against Erysiphe pisi. Physiol. Mol. Plant Pathol., 51, 181194.

Sunkar R.; Kapoor A. and Zhu J.K. (2006). Posttranscriptional induction of two $\mathrm{Cu} / \mathrm{Zn}$ superoxide dismutase genes in Arabidopsis is mediated by downregulation of miR398 and important for oxidative stress tolerance. Plant Cell, 18, 20512065.

Tamreihao K.; Devi L.J.; Khunjamayum R.; Mukherjee S.; Ashem R.S. and Ningthoujam D.S. (2017). Biofertilizing potential of feather hydrolysate produced by indigenous keratinolytic Amycolatopsis sp. MBRL 40 for rice cultivation under field conditions. Biocatalysis and Agricultural Biotechnol 10, 317-320.

Teixeira W.F.; Fagan E.B.; Soares L.H.; Umburanas R.C.; Reichardt K. and Neto D.D. (2017). Foliar and seed application of amino acids affects the antioxidant metabolism of the soybean crop. Frontiers in Plant Sci., 8, 327.

Tran L.T.; Taylor J.S. and Constabel C.P. (2012). The polyphenol oxidase gene family in land plants: Lineage-specific duplication and expansion. BMC Genomics 13, 395.

Vaughn K.C. and Duke S.O. (1984). Function of polyphenol oxidase in higher plants. Physiologia Plantarum 60, 106-112.

Venugoal M. and Saramma A.V. (2006). Characterization of alkaline protease from Vibrio fluvialis strain VM10 isolated from a mangrove sediment sample and its application as a laundry detergent additive. Proc. Biochem., 41, 12391243.

Wen P.F.; Chen J.Y.; Kong W.F.; Qiu-Hong Pan; Si-Bao Wan and Wei-Dong Huang S.B. (2005). Salicylic acid induced the expression of phenylalanine ammonia-lyase gene in grape berry. Plant Sci., 169, 928-934.

Zheng Y.; Sheng J.; Zhao R.; Zhang J.; Lv S.; Liu L. and Shen L. (2011). Preharvest I-arginine treatment induced postharvest disease resistance to Botrytis cinerea in tomato fruits. J. Agric. Food Chem., 59, 6543-6549.

Zitter T.A.; Hopkins D.L. and Thomas C.E. (1996). Compendium of cucurbit diseases. American Phytopathol. Society (APS) Press, Saint Paul. Minnesota, USA. 
مجلة اتحاد الجامعات العربية للعلوم الزراعية، جامعة عين شمس، القاهرة، مصر مجلا(28)، عدد(3)، 827-809، 2020

Website: http://ajs.journals.ekb.eg

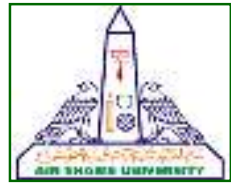

تحسين إنتاج الأحماض الأمينية من ريش الاجاج بواسطة الباسيلس أميلوليكويفاشينز بإستخدام طريقةٌ RSM كطريقة جليدة لمقاومة مرض الأبن البياض الدقيقي

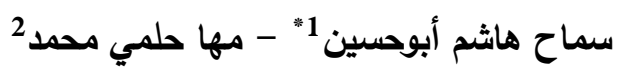

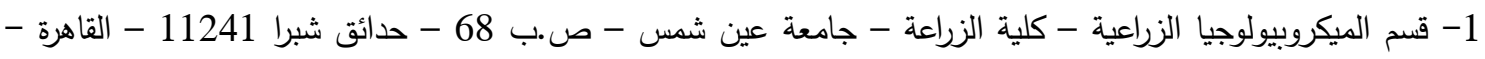

$$
\text { 2- قصم أمراض النبات - كلية الزراعة - جامعة عين شمس - ص.ب } 68 \text { - حدائق شبرا } 11241 \text { - القاهرة - مصر }
$$

*Corresponding author: samah hashem1@agr.asu.edu.eg

Received 22 March, 2020

Accepted 20 April, 2021

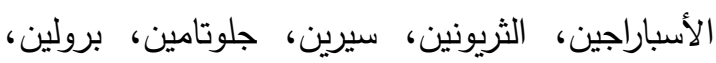

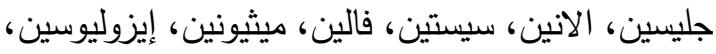

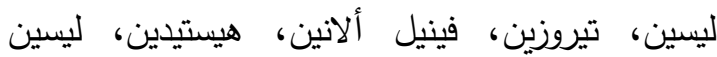

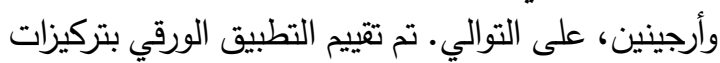

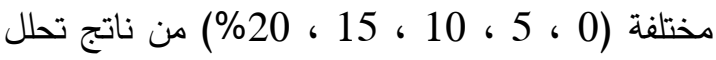
ريش الدجاج على الفطر المسبب لمرض البـ البياض الدقيقي

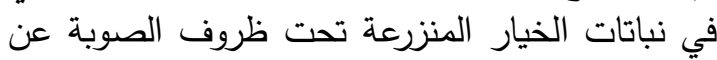
طريق حساب درجة الاصابة والتجرثم. أظهر أقل تركيز

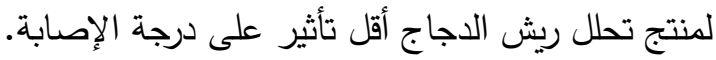

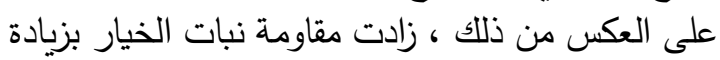

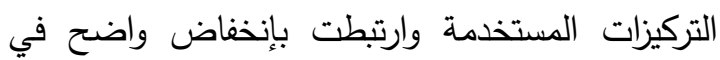

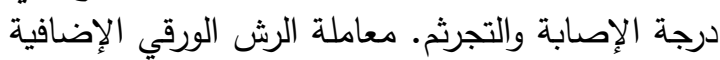

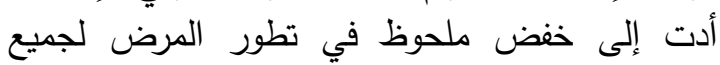

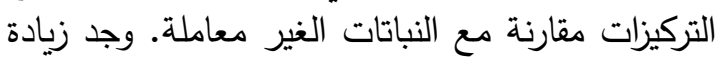
ملحوظة في نشاط الأنزيمات المؤكسدة المرتبطة

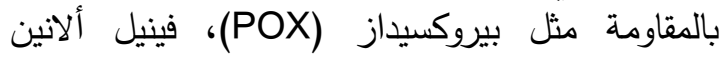

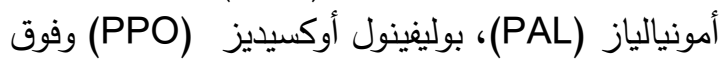

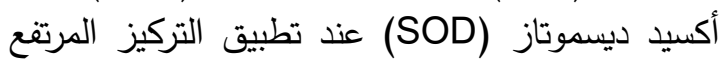
من راشح تحلل الريش.

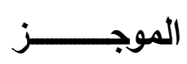

من خلال إستخدام تصميم Plackett Burman design (PBD) (ريش، جلوكوز، مستخلص خميرة، ببتون، كربونات

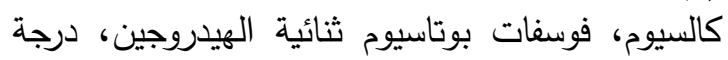

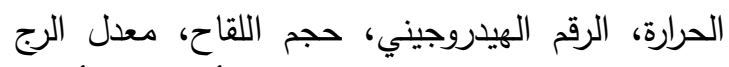
وزمن التحضين) وذلك لتحسين إنتاج الأحماض الأحئ الأمينية الرية

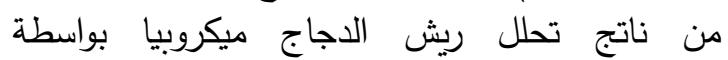
Bacillus amyloliquifaciens 35s. التحليل أن العوامل المؤثرة لإنتاج الأحماض الأمينية

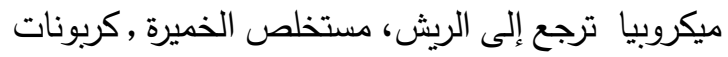
كالسيوم ل الهيدروجين كليوم استخدام الطريقة الاحصائية Central composite design (CCD)

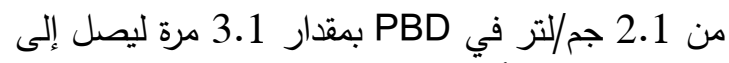
6.55 جم/لتر ـ أظهرت نتائج تحليل الأحماض الأمينية

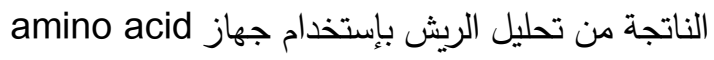
analyzer 